\title{
Zirconia nanoparticle-modified graphitic carbon nitride nanosheets for effective photocatalytic degradation of 4-nitrophenol in water
}

\author{
Mohanna Zarei ${ }^{1} \cdot$ Jamil Bahrami $^{1} \cdot$ Mohammad Zarei $^{1}$ (D)
}

Received: 9 April 2017 / Accepted: 10 October 2019 / Published online: 14 October 2019

(C) The Author(s) 2019

\begin{abstract}
Zirconia $\left(\mathrm{ZrO}_{2}\right)$-modified graphitic carbon nitride $\left(\mathrm{g}-\mathrm{C}_{3} \mathrm{~N}_{4}\right)$ nanocomposite was used for effective photodegradation of 4-nitrophenol (4-NP) in water. The $\mathrm{ZrO}_{2}$ nanoparticles, g- $\mathrm{C}_{3} \mathrm{~N}_{4}$ nanosheets, and $\mathrm{ZrO}_{2} / \mathrm{g}-\mathrm{C}_{3} \mathrm{~N}_{4}$ nanocomposite were well characterized by including $\mathrm{N}_{2}$ adsorption, $\mathrm{X}$-ray diffraction, Fourier transform infrared spectroscopy, field emission scanning electron microscopy, UV-Vis diffuse reflectance spectroscopy, photoelectrochemical measurements, and photoluminescence spectroscopy methods. $\mathrm{ZrO}_{2} / \mathrm{g}-\mathrm{C}_{3} \mathrm{~N}_{4}$ nanocomposites were formed at room temperature using sonication and used for effective for photodegradation of 4-NP under irradiation with visible light. The nanocomposite samples resulted in a significant increase in photocatalytic activity compared with single-component samples of g- $\mathrm{C}_{3} \mathrm{~N}_{4}$. In particular, the $\mathrm{ZrO}_{2} / \mathrm{g}_{-} \mathrm{C}_{3} \mathrm{~N}_{4}$ nanocomposite exhibited the significant increase in the photocatalytic activity. The $\mathrm{ZrO}_{2} / \mathrm{g}-\mathrm{C}_{3} \mathrm{~N}_{4}$ nanocomposite showed an excellent catalytic activity toward the reduction of 4-NP in aqueous medium. Further, $\mathrm{ZrO}_{2} / \mathrm{g}-\mathrm{C}_{3} \mathrm{~N}_{4}$ nanocomposite can be reused several times for photocatalytic degradation as well as for 4-NP adsorption.
\end{abstract}

Keywords Graphitic carbon nitride $\cdot$ Zirconia $\cdot$ Photocatalysis $\cdot$ Water purification $\cdot$ Nanostructures

\section{Introduction}

Extensive global industrial activities have resulted in severe negative impacts on the environment through air and water pollution and generation of large amounts of waste materials. Industrial waste materials consist of both organic and inorganic substances such as pesticide residues, chlorinated and volatile compounds, nitro aromatics, detergents, chemical dyes, and fertilizers. Among the various toxic wastes, dyes and nitro aromatic compounds caused the greatest concern due to their high chemical and biological stability. The US Environmental Protection Agency has declared 4-NP a hazardous pollutant (Atlow et al. 1984; Klibanov et al. 1983). 4-NP can disturb functioning of the human central network system and cause damage to kidneys and the liver

Mohammad Zarei

Mo.zarei@alumni.um.ac.ir

Mohanna Zarei

mohannazarei@eng.uok.ac.ir

Jamil Bahrami

jbahrami@uok.ac.ir

1 Department of Civil Engineering, University of Kurdistan, Sanandaj 66177-15175, Iran
(Pohanish 2008; Zarei et al. 2016). Thus, removal of 4-NP from polluted water is essential. Traditional water remediation treatments are not effective for the removal of 4-NP due to its stability and solubility in water. Therefore, recently, the scientific community has given focused on inventing efficient catalysts for the degradation of 4-NP (Chang et al. 2012; Pradhan et al. 2002).

Semiconductor photocatalysis is the emerging advanced oxidation method for abatement of organic pollutants and possesses several advantages over traditional oxidation methods. One of the merits of semiconductor photocatalysis is the ability of adsorbing a wide range of organic and inorganic species on the surface of the photocatalyst which chemically alters by light-induced redox reaction. Various types of photocatalysts for use in air or water purification applications have been designed (Pawar et al. 2015). Combinations of metal/metal oxide nanoparticles (NPs) such as Au, $\mathrm{Ag}, \mathrm{Pt}, \mathrm{TiO}_{2}, \mathrm{ZnO}, \mathrm{SnO}_{2}, \mathrm{WO}_{3}, \mathrm{Nb}_{2} \mathrm{O}_{5}, \mathrm{BiVO}_{4}$, and $\mathrm{Fe}_{2} \mathrm{O}_{3}$ with conducting polymers such as polyaniline, polypyrrole, and polythiophene have been utilized for the degradation of organic pollutants (Ge et al. 2013; Jiang et al. 2014; Reimer et al. 2014; Wang and Astruc 2014; Wang et al. 2014; Xu et al. 2014; Zhang et al. 2015b). The small dimensions induce a significant change in the reduction potential of 
metal NPs compared to bulk materials. This unique characteristic improves the electron transfer process in various catalysis reactions. However aggregation, agglomeration, and high surface energy of NPs reduce the feasibility of NP applications as photocatalysts. In order to reduce aggregation, NPs can be stabilized on the surface of a solid support (Campelo et al. 2009). Carbonaceous nanomaterials are interesting candidates due to their exotic physical and chemical characteristics (Geim 2009) such as high surface area, high electrical-thermal conductivity, high charge carrier mobility, and extraordinary mechanical strength, and graphene allotropes are a promising material for support of different NPs. The graphene support which contains metal or semiconductor NPs has been confirmed to be effective nanocomposite material for the photovoltaic cell (Ong et al. 2015a; Yeh et al. 2015), catalysis, and biosensor applications (Guo and Dong 2011). Recently, another two-dimensional carbonaceous material, $\mathrm{g}-\mathrm{C}_{3} \mathrm{~N}_{4}$, has attracted significant attention (Gao et al. 2014; Maeda et al. 2014; Tan et al. 2015; Tian et al. 2014; Wang et al. 2012; Wu et al. 2014; Zheng et al. 2012). Unique properties of $\mathrm{g}-\mathrm{C}_{3} \mathrm{~N}_{4}$ including good visible-light absorption, moderate band gap $(2.7 \mathrm{eV})$, high thermal and chemical stability, and photocatalytic properties introduce a new material for application in photocatalysis (Pawar et al. 2016a, 2017). The $\mathrm{g}_{-} \mathrm{C}_{3} \mathrm{~N}_{4}$ and $\mathrm{g}-\mathrm{C}_{3} \mathrm{~N}_{4}$-based structures have been used in various applications such as photo catalytic degradation of microbial, organic, and inorganic pollutants (Lan et al. 2015; Li et al. 2015; Papailias et al. 2015; Pawar et al. 2015, 2016b), hydrogen evolution from water splitting (Liang et al. 2015; Liu et al. 2015b; Xu et al. 2015; Yang et al. 2015b), sensors applications (Pany and Parida 2015; Wang et al. 2015; Zhang et al. 2015a), adsorption (Anbia and Haqshenas 2015; Chen et al. 2015; Hu et al. 2015), reduction of oxygen (Lu et al. 2015; Zhao et al. 2015), lithium-ion batteries (Liu et al. 2015a; Luo et al. 2015), biofuel cells (Yi et al. 2015), and photochemo combination methods (Yang et al. 2015a). Due to repeating triazine units, the $\mathrm{g}_{-} \mathrm{C}_{3} \mathrm{~N}_{4}$ consists of a large number of binding sites which can stabilize the NPs, making this $\mathrm{g}_{-} \mathrm{C}_{3} \mathrm{~N}_{4}$ a promising support for NPs (Huang et al. 2015; Ong et al. 2015b). Thus, $\mathrm{g}-\mathrm{C}_{3} \mathrm{~N}_{4}$ nanosheet can be used as a feasible candidate for stabilizing metal NPs for catalytic applications (Wang et al. 2009). This material is used for the degradation of organic pollutants and photocatalytic reduction of $\mathrm{CO}_{2}$ under visible light (Mao et al. 2013; Yan et al. 2009). However, it suffers from a high charge carrier recombination rate and low quantum efficiency which lead to poor photocatalytic performance (Wang et al. 2012). Sensitization and combination with semiconductor NPs (namely $\mathrm{Au}, \mathrm{Ag}, \mathrm{Pt}$, and Pd) and carbon-based materials (CNTs and graphene) are the most viable routes for improving the $\mathrm{g}-\mathrm{C}_{3} \mathrm{~N}_{4}$-based photocatalysts (Sridharan et al. 2014). Among the metal oxide NPs, $\mathrm{ZrO}_{2}$ is a material with favored properties including high stability, high toughness, high chemical strength, desirable corrosion, chemical and microbial resistance (Polisetti et al. 2011; Singh and Nakate 2014). Moreover, $\mathrm{ZrO}_{2}$ NPs have plenty of oxygen vacancies on surfaces with wideband-gap P-type semiconductors. The high ion exchange ability and redox movement make it useful in many catalytic processes as a catalyst (Fidelus et al. 2012).

Here, we report a facile ultrasonication method for the fabrication of hybrid nanocomposites using $\mathrm{ZrO}_{2} \mathrm{NPs}$, and g- $\mathrm{C}_{3} \mathrm{~N}_{4}$ nanosheets and their application for photocatalytic degradation of 4-NP in water. Mono-dispersed $\mathrm{ZrO}_{2} \mathrm{NPs}$ were dispersed on carbon nitride sheets by ultrasound. The $\mathrm{ZrO}_{2} / \mathrm{g}-\mathrm{C}_{3} \mathrm{~N}_{4}$ composite exhibited superior catalytic activity toward the reduction of 4-NP. Possible mechanism for degradation of 4-NP upon $\mathrm{ZrO}_{2} / \mathrm{g}-\mathrm{C}_{3} \mathrm{~N}_{4}$ catalyst under light irradiation was proposed. The $\mathrm{ZrO}_{2} / \mathrm{g}-\mathrm{C}_{3} \mathrm{~N}_{4}$ catalyst is very efficient for the removal of 4-NP from aqueous environment by its dual actions with adsorption and photocatalytic degradation of 4-NP.

\section{Materials and methods}

\section{Materials}

All reagents were of analytical grade. Hydrochloric acid and ammonia were purchased from Merck. $\mathrm{ZrOCl}_{2} \cdot 8 \mathrm{H}_{2} \mathrm{O}$, $\mathrm{KOH}$, and nitric acid were purchased from Sigma-Aldrich. Melamine (99\%) was prepared from Sigma-Aldrich and used without further purification. P25 titanium dioxide $\left(\mathrm{TiO}_{2}\right)$ powder was obtained from Degussa (rutile/anatase: 85:15, 99.9\%).

\section{Synthesis of $\mathrm{ZrO}_{2} \mathrm{NPs}$}

In a typical synthesis, $0.1 \mathrm{M}$ of $\mathrm{ZrOCl}_{2} \cdot 8 \mathrm{H}_{2} \mathrm{O}$ was dissolved in $100 \mathrm{~mL}$ of distilled water. Then, $0.3 \mathrm{M}$ of $\mathrm{KOH}$ was added to the above solution. The final solution was transferred into a stainless steel Teflon-lined sterilized capacity of $100 \mathrm{~mL}$ and kept in an oven at $180{ }^{\circ} \mathrm{C}$ for $16 \mathrm{~h}$. The resulting precipitates were washed with distilled water and ethanol. The resultant was dried for $3 \mathrm{~h}$ in vacuum at $80^{\circ} \mathrm{C}$.

\section{Synthesis of $\mathrm{g}-\mathrm{C}_{3} \mathrm{~N}_{4}$ nanosheets}

In a typical synthesis, $30 \mathrm{~g}$ melamine was placed in a crucible and then heated at $600{ }^{\circ} \mathrm{C}$ for $2 \mathrm{~h}$, resulting in yellow powder. Liquid exfoliating method was applied to produce the $\mathrm{g}-\mathrm{C}_{3} \mathrm{~N}_{4}$ nanosheets from bulk material. In brief, $70 \mathrm{mg}$ of the bulk $\mathrm{g}-\mathrm{C}_{3} \mathrm{~N}_{4}$ powder was dispersed in $100 \mathrm{~mL}$ water and the mixture was ultrasounded for $6 \mathrm{~h}$. The final suspension was then centrifuged at 10,000 rpm and dried for $3 \mathrm{~h}$ in vacuum at $80{ }^{\circ} \mathrm{C}$ (Tian et al. 2013). 


\section{Fabrication of $\mathrm{ZrO}_{2} / \mathrm{g}-\mathrm{C}_{3} \mathrm{~N}_{4}$ hybrids}

The $\mathrm{ZrO}_{2} \mathrm{NPs}$ was incorporated into $\mathrm{g}-\mathrm{C}_{3} \mathrm{~N}_{4}$ sheets using ultrasonication at room temperature. Then, $50 \mathrm{mg}$ of g- $\mathrm{C}_{3} \mathrm{~N}_{4}$ powder was added to $20 \mathrm{~mL}$ of the $\mathrm{ZrO}_{2}$ colloidal dispersion and ultrasonicated for $2 \mathrm{~h}$ at $30{ }^{\circ} \mathrm{C}$. The $\mathrm{ZrO}_{2} / \mathrm{g}-\mathrm{C}_{3} \mathrm{~N}_{4}$ dispersion was then filtered and washed several times using ethanol. The resulting $\mathrm{ZrO}_{2} / \mathrm{g}-\mathrm{C}_{3} \mathrm{~N}_{4}$ powder was collected and dried overnight at $60{ }^{\circ} \mathrm{C}$.

\section{Characterization methods}

The X-ray diffraction (XRD) pattern of the nanomaterials was obtained by using a powder X-ray diffractometer model Shimadzu XRD 6000 using CuKa with a diffraction angle between $20^{\circ}$ and $80^{\circ}$. The crystallite size was determined using Scherrer's formula. Field emission Scanning electron microscopy (FESEM) studies were carried out on TSCAN. UV-Vis absorption spectrum for the samples was recorded using a Varian spectrophotometer in the range of 300-700 nm. The Fourier transform infrared spectroscopy (FTIR) spectrum of the $\mathrm{ZrO}_{2}$ NPs was taken using an FTIR model THERMO NICOLET Spectrometer. The photoluminescence (PL) spectrum of the $\mathrm{ZrO}_{2}$ particles was recorded by the PerkinElmer lambda spectrophotometer with a Xenon lamp as the excitation light source.

\section{Photocatalytic degradation}

The photocatalytic activities of $\mathrm{ZrO}_{2} / \mathrm{g}-\mathrm{C}_{3} \mathrm{~N}_{4}$ hybrids were evaluated at room temperature. Thirty-sixty milligrams of sample was dispersed into the $100 \mathrm{~mL}$ of $30 \mathrm{mg} / \mathrm{L} \mathrm{4-NP}$ solution with magnetic stirring in each experiment. Prior to irradiation, the suspensions were magnetically stirred in the dark for $60 \mathrm{~min}$ to reach an adsorption/desorption equilibrium between the catalyst and 4-NP solution. Then, the solution was exposed to simulated solar light under magnetic stirring. At given reaction time of approximately $2 \mathrm{~h}, 4 \mathrm{~mL}$ of the solution was pipetted every $10 \mathrm{~min}$ and centrifuged to separate the catalyst. Concentration of 4-NP solution was measured by a UV-visible spectrophotometer at $\lambda=500 \mathrm{~nm}$ to evaluate the degradation rate. The examination experiment of reactive species is similar to the photodegradation experiment. The catalytic degradation efficiency of 4-NP was calculated using Eq. (1):

$\%$ Degradation Efficiency $=\frac{C_{0}-C_{\mathrm{e}}}{C_{0}} 100$ where $C_{0}$ is initial concentration of 4-NP solution $\left(\mathrm{mg} \mathrm{L}^{-1}\right)$ and $C_{\mathrm{e}}$ is the equilibrium concentration of 4-NP solution $\left(\mathrm{mg} \mathrm{L}^{-1}\right)$.

\section{Photoelectrochemical measurements}

Photoelectrochemical (PEC) performance was analyzed using a three-electrode in quartz cell. Graphite served as the counter electrode, and $\mathrm{Ag} / \mathrm{AgCl}$ served as the reference. The PEC measurements were taken using a Xe arc lamp (300 W, model 66984; Oriel, USA) with the electrolyte solution of $\mathrm{Na}_{2} \mathrm{SO}_{4}(0.5 \mathrm{M})$. For preparation of working electrodes, $10 \mathrm{mg}$ of $\mathrm{g}-\mathrm{C}_{3} \mathrm{~N}_{4}$ powder was added to $10 \mathrm{~mL}$ of Liquion solution, and the resulted mixture was ultrasonicated for $1 \mathrm{~h}$ and stirred overnight. This suspension was spin-coated on a fluorine-doped tin oxide (FTO) glass substrate at ambient conditions. At final stage, in order to increase the uniform distribution of the catalyst on the substrate, the prepared FTO films spin-coated with the catalysts were heated in oven at $60{ }^{\circ} \mathrm{C}$ for $2 \mathrm{~h}$ (Pawar et al. 2016a).

\section{Results and discussion}

\section{Characterizations of $\mathrm{ZrO}_{2} / \mathrm{g}-\mathrm{C}_{3} \mathrm{~N}_{4}$ composites}

Figure 1a-c shows the XRD patterns of the $\mathrm{g}-\mathrm{C}_{3} \mathrm{~N}_{4}, \mathrm{ZrO}_{2}$, and $\mathrm{ZrO}_{2} / \mathrm{g}-\mathrm{C}_{3} \mathrm{~N}_{4}$ nanocomposites. The diffraction peaks of $\mathrm{ZrO}_{2}$ NPs can be assigned to the monoclinic phase. $\mathrm{ZrO}_{2}$ NPs are spherical with an average particle size of $15 \mathrm{~nm}$, which leads to its high surface area of $73.9 \mathrm{~m}^{2} \mathrm{~g}^{-1}$. However, pure $\mathrm{g}-\mathrm{C}_{3} \mathrm{~N}_{4}$ has a low surface area of $51.8 \mathrm{~m}^{2} \mathrm{~g}^{-1}$, which can be attributed to its special morphology. The BET surface area analysis applied using the $\mathrm{N}_{2}$ adsorption method illustrates that the incorporation of $\mathrm{ZrO}_{2}$ NPs increases the surface area of $\mathrm{g}^{-} \mathrm{C}_{3} \mathrm{~N}_{4}$ nanosheets. The BET surface area of $10 \mathrm{wt} \% \mathrm{ZrO}_{2} / \mathrm{g}-\mathrm{C}_{3} \mathrm{~N}_{4}$ and $30 \mathrm{wt} \% \mathrm{ZrO}_{2} / \mathrm{g}_{-} \mathrm{C}_{3} \mathrm{~N}_{4}$ samples was 59.12 and $65.3 \mathrm{~m}^{2} \mathrm{~g}^{-1}$, respectively. The BET surface areas result shows that the addition of $\mathrm{ZrO}_{2}$ increases the surface area of $\mathrm{g}-\mathrm{C}_{3} \mathrm{~N}_{4}$. The strong and sharp $\mathrm{ZrO}_{2}$ diffraction peaks demonstrate that the samples have high crystallinity. The XRD patterns show no extra diffraction peaks indicating the high level of purity of the samples. Diffraction peaks of $\mathrm{g}-\mathrm{C}_{3} \mathrm{~N}_{4}$ at $12.8^{\circ}$ and $27.6^{\circ}$ confirmed that $\mathrm{g}-\mathrm{C}_{3} \mathrm{~N}_{4}$ was formed. The XRD patterns of $\mathrm{ZrO}_{2} / \mathrm{g}-\mathrm{C}_{3} \mathrm{~N}_{4}$ hybrid samples contain the peaks of both $\mathrm{ZrO}_{2} \mathrm{NPs}$ and g- $\mathrm{C}_{3} \mathrm{~N}_{4}$ nanosheets and show that after synthesis of $\mathrm{ZrO}_{2} / \mathrm{g}-\mathrm{C}_{3} \mathrm{~N}_{4}$ composite, the crystal structure of $\mathrm{ZrO}_{2}$ and $\mathrm{g}-\mathrm{C}_{3} \mathrm{~N}_{4}$ did not change. Figure 1d-f illustrates field emission scanning emission microscopy (FESEM) images of the $\mathrm{ZrO}_{2}, \mathrm{~g}-\mathrm{C}_{3} \mathrm{~N}_{4}$, and $\mathrm{ZrO}_{2} / \mathrm{g}_{-} \mathrm{C}_{3} \mathrm{~N}_{4}$ hybrid samples which show the planar structure of $\mathrm{g}-\mathrm{C}_{3} \mathrm{~N}_{4}$ nanosheets as well as the spherical structure of $\mathrm{ZrO}_{2} \mathrm{NPs}$. 

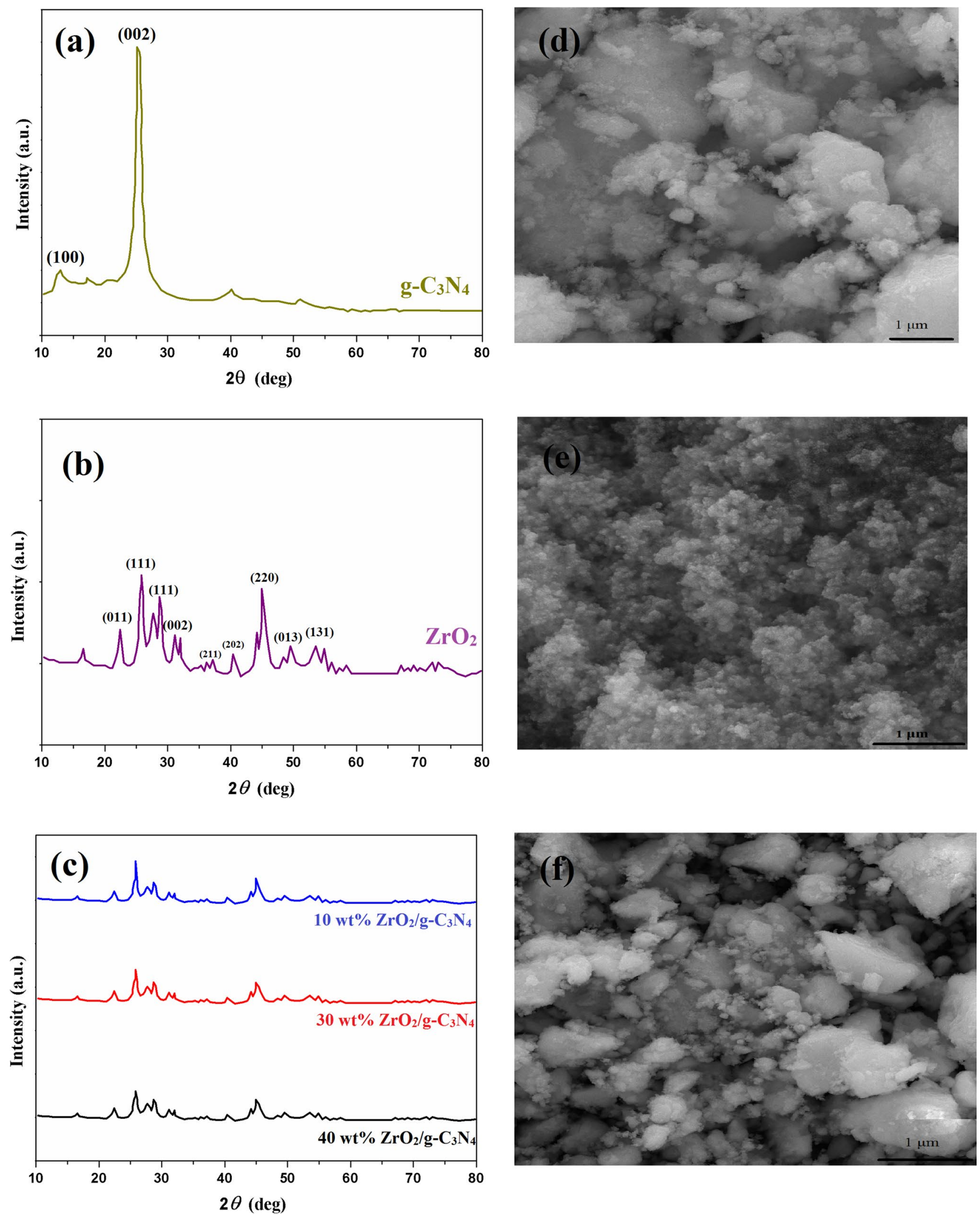

Fig. 1 XRD patterns of a $\mathrm{g}_{-} \mathrm{C}_{3} \mathrm{~N}_{4}$, b $\mathrm{ZrO}_{2}$ and $\mathbf{c} \mathrm{ZrO}_{2} / \mathrm{g}-\mathrm{C}_{3} \mathrm{~N}_{4}$ composites with different $\mathrm{ZrO}_{2}$ concentrations. FESEM images of $\mathbf{d}$ g- $\mathrm{C}_{3} \mathrm{~N}_{4}$, e $\mathrm{ZrO}_{2}$, and f $20.9 \mathrm{wt} \% \mathrm{ZrO}_{2} / \mathrm{g}-\mathrm{C}_{3} \mathrm{~N}_{4}$ composite (e and

f). (green color: $\mathrm{g}-\mathrm{C}_{3} \mathrm{~N}_{4}$, violet color: $\mathrm{ZrO}_{2}$, blue color: $10 \mathrm{wt} \%$ $\mathrm{ZrO}_{2} / \mathrm{g}-\mathrm{C}_{3} \mathrm{~N}_{4}$, red color: $30 \mathrm{wt} \% \mathrm{ZrO}_{2} / \mathrm{g}-\mathrm{C}_{3} \mathrm{~N}_{4}$, block color: $40 \mathrm{wt} \%$ $\mathrm{ZrO}_{2} / \mathrm{g}-\mathrm{C}_{3} \mathrm{~N}_{4}$ ) 

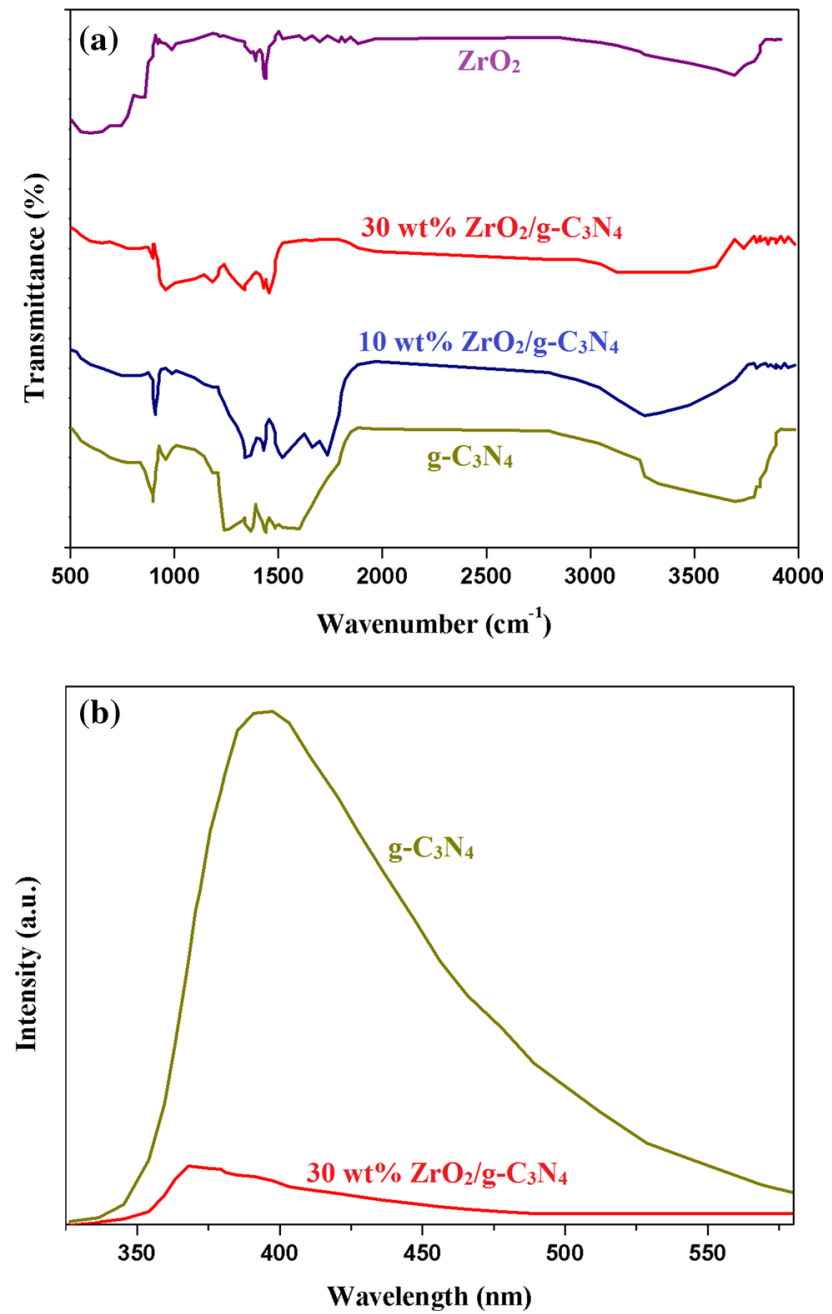

Fig. 2 a FTIR spectra of $\mathrm{ZrO}_{2} / g-\mathrm{C}_{3} \mathrm{~N}_{4}$ composites with different $\mathrm{ZrO}_{2}$ concentrations, b PL spectra of $\mathrm{g}-\mathrm{C}_{3} \mathrm{~N}_{4}$ and $30 \mathrm{wt} \% \mathrm{ZrO}_{2} / \mathrm{g}-\mathrm{C}_{3} \mathrm{~N}_{4}$

Figure 2a shows the FTIR spectra for $\mathrm{ZrO}_{2}, \mathrm{~g}_{-} \mathrm{C}_{3} \mathrm{~N}_{4}$, and $\mathrm{ZrO}_{2} / \mathrm{g}_{-} \mathrm{C}_{3} \mathrm{~N}_{4}$ nanocomposites. For $\mathrm{ZrO}_{2}$, the broad bands at the range $500-550 \mathrm{~cm}^{-1}$ and $800 \mathrm{~cm}^{-1}$ are related to the $\mathrm{Zr}-\mathrm{O}$ vibration absorption (Zhang et al. 2013). Furthermore, the broad region with a maximum of about $3350 \mathrm{~cm}^{-1}$ can be related to the hydroxyl groups of hydrated oxide. For g- $\mathrm{C}_{3} \mathrm{~N}_{4}$, the sharp peaks in the range of $1200-1700 \mathrm{~cm}^{-1}$ can be attributed to the stretching vibration of the breathing mode of triazine units (Sayama and Arakawa 1993). In addition, a broad absorption band with a maximum of around $3200-3700 \mathrm{~cm}^{-1}$ can be attributed to the $\mathrm{N}-\mathrm{H}$ groups (Sayama and Arakawa 1993). There is a similarity between the FTIR spectra of $\mathrm{ZrO}_{2} / \mathrm{g}-\mathrm{C}_{3} \mathrm{~N}_{4}$ and pure g- $\mathrm{C}_{3} \mathrm{~N}_{4}$. However, the change in the bands of 800 and $3300 \mathrm{~cm}^{-1}$ with the variation of $\mathrm{ZrO}_{2}$ concentration still demonstrates the presence of $\mathrm{ZrO}_{2}$ NPs. The FTIR result shows good correlation with $\mathrm{XRD}$ results and shows the hybrids structure of $\mathrm{ZrO}_{2} / \mathrm{g}-\mathrm{C}_{3} \mathrm{~N}_{4}$ nanocomposite (Sayama and Arakawa 1993).
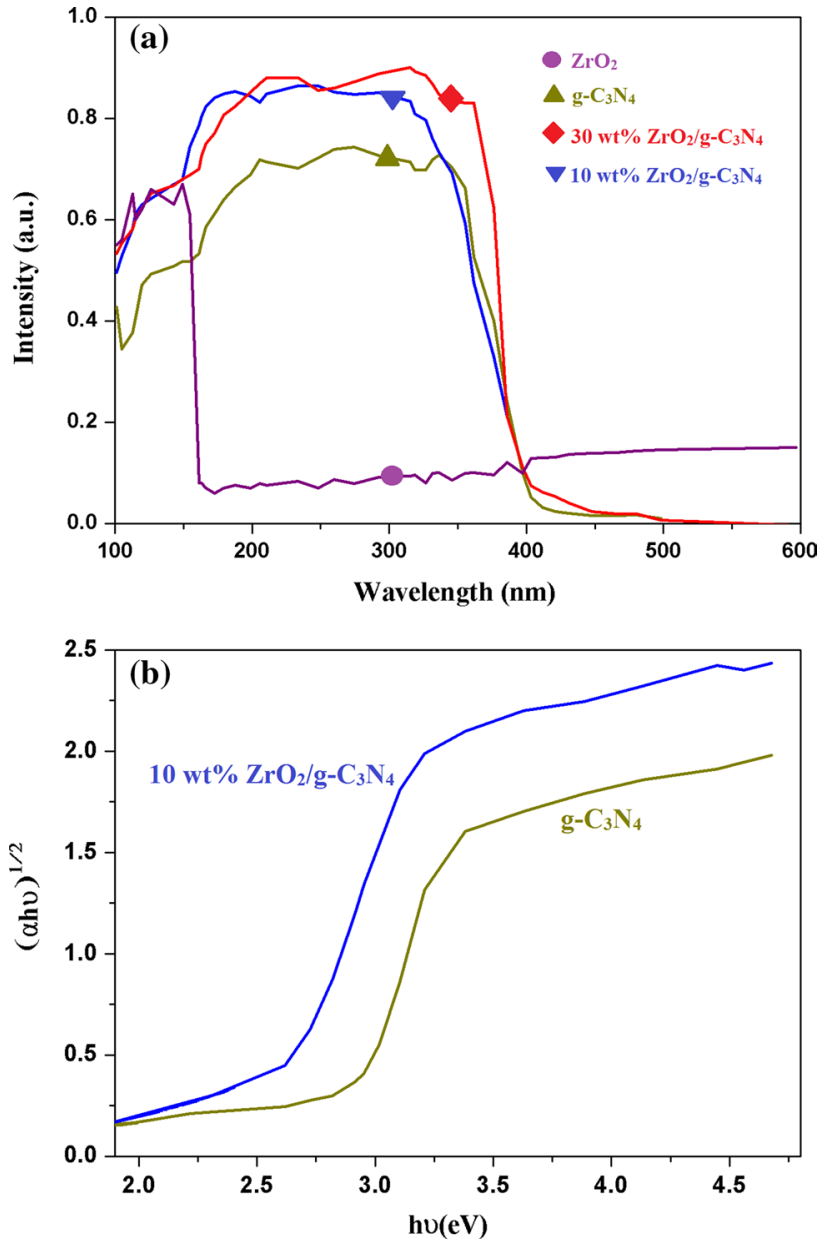

Fig. 3 a UV-Vis diffuse reflectance spectra (DRS) of pure g-C3N4, $\mathrm{ZrO}_{2}, 10 \mathrm{wt} \% \mathrm{ZrO}_{2} / \mathrm{g}-\mathrm{C}_{3} \mathrm{~N}_{4}, 30 \mathrm{wt} \% \mathrm{ZrO}_{2} / \mathrm{g}-\mathrm{C}_{3} \mathrm{~N}_{4}$ and $\mathbf{b}$ the optical absorption edges of the representative $10 \mathrm{wt} \% \mathrm{ZrO}_{2} / \mathrm{g}-\mathrm{C}_{3} \mathrm{~N}_{4}$ and pure $\mathrm{g}-\mathrm{C}_{3} \mathrm{~N}_{4}$

Figure $2 \mathrm{~b}$ shows the influence of the $\mathrm{ZrO}_{2} / \mathrm{g}-\mathrm{C}_{3} \mathrm{~N}_{4}$ hetero-junction on the separation efficiency of electron-hole pairs which was investigated by PL spectra. Sharp emission peak at around $380 \mathrm{~nm}$ in unmodified $\mathrm{g}-\mathrm{C}_{3} \mathrm{~N}_{4}$ related to the band gap transition emission which is equal to the band gap energy of unmodified $\mathrm{g}_{-} \mathrm{C}_{3} \mathrm{~N}_{4}$. However, fluorescence quenching can be observed in the similar position in the PL spectrum of $\mathrm{ZrO}_{2} / g-\mathrm{C}_{3} \mathrm{~N}_{4}$. Further, charge transfer between g- $\mathrm{C}_{3} \mathrm{~N}_{4}$ and $\mathrm{ZrO}_{2}$ component prevents the electron-hole recombination.

Compared with that of $\mathrm{g}_{-} \mathrm{C}_{3} \mathrm{~N}_{4}$, the emission intensities of $\mathrm{ZrO}_{2} / \mathrm{g}-\mathrm{C}_{3} \mathrm{~N}_{4}$ are much lower, which indicate that a good separation of electrons and holes is achieved by introducing $\mathrm{ZrO}_{2} \mathrm{NPs}$ to the $\mathrm{g}-\mathrm{C}_{3} \mathrm{~N}_{4}$ nanosheets.

The ability to absorb the light by photocatalysts is important to generate the charge carriers. Therefore, we measured the optical characteristics in $\mathrm{g}-\mathrm{C}_{3} \mathrm{~N}_{4}, \mathrm{ZrO}_{2}$, and $\mathrm{ZrO}_{2} / \mathrm{g}-\mathrm{C}_{3} \mathrm{~N}_{4}$ nanocomposites using the $\mathrm{UV}-\mathrm{V}$ is diffuse reflectance 
spectroscopy (DRS) technique. As shown in Fig. 3a, $\mathrm{ZrO}_{2}$ NPs absorbed the light with a wavelength shorter than $170 \mathrm{~nm}$ have band gap energy of about $4.8 \mathrm{eV}$. In pure $\mathrm{g}^{-} \mathrm{C}_{3} \mathrm{~N}_{4}$, the absorbance edge is located at $415 \mathrm{~nm}$, revealing the standard absorption threshold of $\mathrm{g}^{-} \mathrm{C}_{3} \mathrm{~N}_{4}$ structure (Wang et al. 2009; Yan et al. 2009). Because of interactions between $\mathrm{ZrO}_{2}$ and $g-\mathrm{C}_{3} \mathrm{~N}_{4}$, the $\mathrm{ZrO}_{2} / \mathrm{g}-\mathrm{C}_{3} \mathrm{~N}_{4}$ nanocomposite (10, $\left.30 \mathrm{wt} \% \mathrm{ZrO}_{2} / \mathrm{g}_{-} \mathrm{C}_{3} \mathrm{~N}_{4}\right)$ shows better photo absorption performance than pure $\mathrm{g}-\mathrm{C}_{3} \mathrm{~N}_{4}$. Different chemical bonds formed between the $\mathrm{ZrO}_{2}$ and $\mathrm{g}-\mathrm{C}_{3} \mathrm{~N}_{4}$ might result in the enhanced optical property which is similar to that in the $\mathrm{N}$-doped $\mathrm{ZrO}_{2}$ (Zhao et al. 2014) and $\mathrm{TiO}_{2}$-doped graphene photocatalyst (Leary and Westwood 2011; Woan et al. 2009). According to DRS results, $\mathrm{ZrO}_{2} / g-\mathrm{C}_{3} \mathrm{~N}_{4}$ nanocomposite shows an efficient visible-light photocatalytic activity. When $\mathrm{ZrO}_{2}$ was incorporated into $\mathrm{g}-\mathrm{C}_{3} \mathrm{~N}_{4}$ nanosheets, the corresponding band edge absorption was shifted to longer wavelength in comparison with the pure g- $\mathrm{C}_{3} \mathrm{~N}_{4}$. The nanocomposite structures of $30 \mathrm{wt} \% \mathrm{ZrO}_{2} / \mathrm{g}_{-} \mathrm{C}_{3} \mathrm{~N}_{4}$ exhibited maximum absorption in the visible region of spectrum. Moreover, we estimated band gap energy of pure g- $\mathrm{C}_{3} \mathrm{~N}_{4}$ and $\mathrm{ZrO}_{2} / \mathrm{g}_{-} \mathrm{C}_{3} \mathrm{~N}_{4}$ nanocomposite from optical absorption, and the corresponding plots are shown in Fig. 3b. The direct band gap of pure $\mathrm{ZrO}_{2}$ is calculated to be $5.20 \mathrm{eV}$, which is seen to be not useful in visible region of solar spectrum. However, after making nanocomposite with $\mathrm{g}-\mathrm{C}_{3} \mathrm{~N}_{4}$, it shifted toward visible region. The obtained band gap of pure $\mathrm{g}_{-} \mathrm{C}_{3} \mathrm{~N}_{4}$ is found to be $2.75 \mathrm{eV}$, which can be used in visible irradiation. Additionally, nanocomposite structure exhibited band edge absorption around $2.6 \mathrm{eV}$, indicating its applicability in visible light. Figure 3 a shows the UV-Vis spectra of all the $\mathrm{ZrO}_{2}$ samples have extended a red shift and significant absorption between 100 and $450 \mathrm{~nm}$. This red shift translates into a decrease in the band gaps of the nanocomposites which leads to more absorption in the visible region and hence better photocatalytic activity. In general, the red shift and absorption intensity both increased with higher $\mathrm{ZrO}_{2}$ concentration. In addition, the optical spectra of the $\mathrm{ZrO}_{2} / \mathrm{g}-\mathrm{C}_{3} \mathrm{~N}_{4}$ display clear red shifts with respect to that of pure $\mathrm{g}-\mathrm{C}_{3} \mathrm{~N}_{4}$ which is consistent with the band gaps calculated from the DRS results. The enhanced visible-light absorption of $\mathrm{ZrO}_{2} / \mathrm{g}-\mathrm{C}_{3} \mathrm{~N}_{4}$ materials makes them ideal candidates for photocatalysts. Hence, the band gap value of the nanocomposite decreases by increasing the amount of $\mathrm{g}-\mathrm{C}_{3} \mathrm{~N}_{4}$. This result indicated the strong interaction between $\mathrm{ZrO}_{2}$ and $\mathrm{g}-\mathrm{C}_{3} \mathrm{~N}_{4}$ nanosheets in the nanocomposite.

\section{Photocatalytic degradation of 4-NP}

Figure 4 shows the degradation of 4-NP under visible-light irradiation for determination of photocatalytic activity of $\mathrm{ZrO} 2, \mathrm{~g}-\mathrm{C}_{3} \mathrm{~N}_{4}$, and $\mathrm{ZrO}_{2} / \mathrm{g}-\mathrm{C}_{3} \mathrm{~N}_{4}$ nanocomposites. For comparison, the degradation of 4-NP by $\mathrm{TiO}_{2}$ powder was
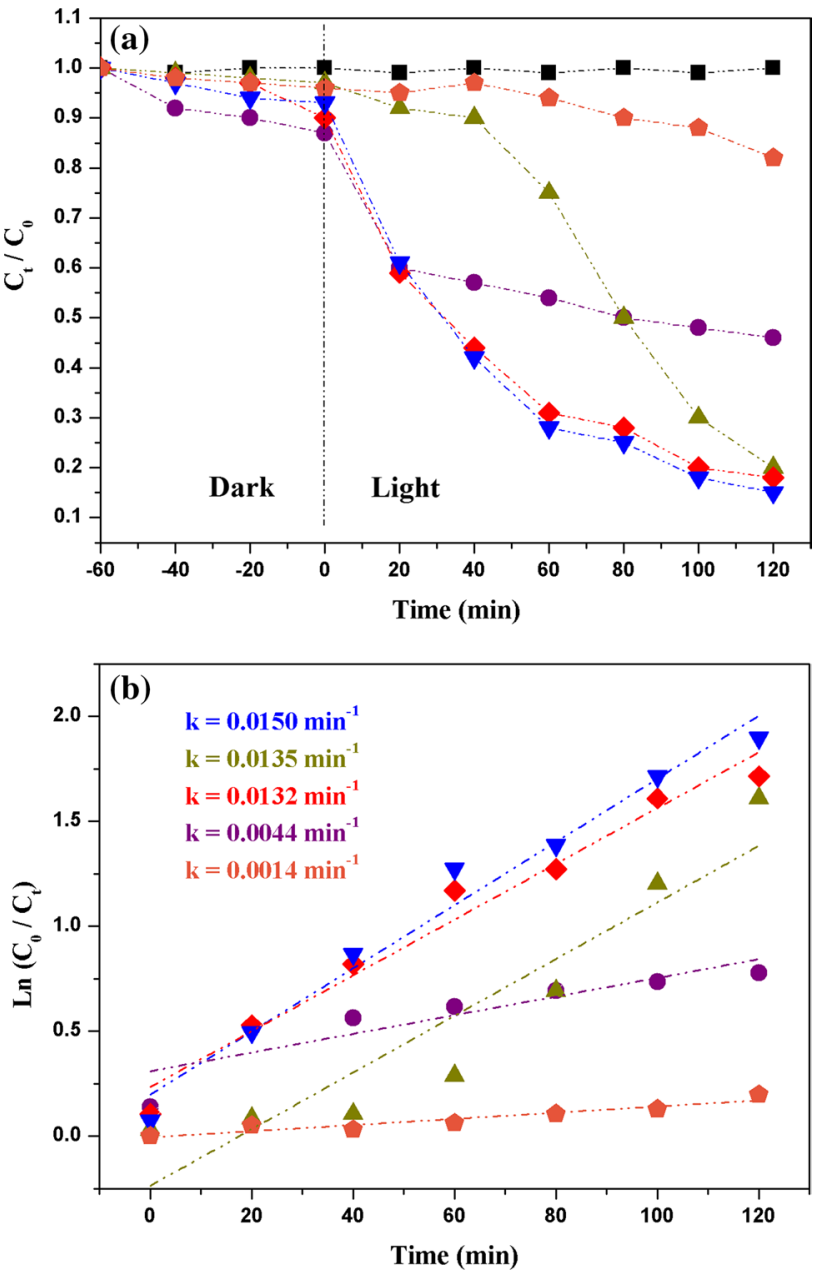

Fig. 4 a Photodegradation of 4-NP on $\mathrm{ZrO}_{2} / \mathrm{g}-\mathrm{C}_{3} \mathrm{~N}_{4}$ nanocomposites under light irradiation and $\mathbf{b}$ the corresponding reactive constant (green color triangle: $\mathrm{g}-\mathrm{C}_{3} \mathrm{~N}_{4}$, violet color circle: $\mathrm{ZrO}_{2}$, red color diamond: $10 \mathrm{wt} \% \mathrm{ZrO}_{2} / \mathrm{g}-\mathrm{C}_{3} \mathrm{~N}_{4}$, blue color down triangle: $30 \mathrm{wt} \%$ $\mathrm{ZrO}_{2} / \mathrm{g}-\mathrm{C}_{3} \mathrm{~N}_{4}$, brown color pentagon: $\mathrm{TiO}_{2}$, block color square: blank)

analyzed as a standard material. The blank test shows that 4-NP is stable under visible-light irradiation, which indicates that the contribution of 4-NP photolysis can be neglected. Also, $\mathrm{ZrO}_{2} \mathrm{NP}$ has a high surface area and demonstrated the stable adsorption for 4-NP. Elevated 4-NP concentration at the beginning of the light-on was attributed to desorption of some 4-NPs due to the increased temperature on the $\mathrm{ZrO}_{2}$ surface. In irradiation time longer than $30 \mathrm{~min}$, the concentration of 4-NP gradually decreases.

Compared to $\mathrm{ZrO}_{2}$, pure $\mathrm{g}-\mathrm{C}_{3} \mathrm{~N}_{4}$ shows weaker adsorption of 4-NP but higher photoactivity under visible-light irradiation. The rate of 4-NP degradation is $0.0116 \mathrm{~min}^{-1}$ which is higher than that of $\mathrm{ZrO}_{2}\left(0.0022 \mathrm{~min}^{-1}\right)$. The incorporation of $\mathrm{ZrO}_{2} \mathrm{NPs}$ on $\mathrm{g}^{-} \mathrm{C}_{3} \mathrm{~N}_{4}$ nanosheets can improve the electron-hole separation efficiency and also in absorption of light. Thus, the catalytic activity for 4-NP degradation is enhanced. By loading of $\mathrm{ZrO}_{2} \mathrm{NPs}$ with 
concentration from 10 to $30 \mathrm{wt} \%$, the photocatalytic activity of $\mathrm{ZrO}_{2} / g-\mathrm{C}_{3} \mathrm{~N}_{4}$ increases. According to the results, the $30 \mathrm{wt} \% \mathrm{ZrO}_{2} / \mathrm{g}-\mathrm{C}_{3} \mathrm{~N}_{4}$ sample demonstrates the highest degradation rate of $0.0167 \mathrm{~min}^{-1}$ which is higher than that of pure g- $\mathrm{C}_{3} \mathrm{~N}_{4}$ nanosheets. Also, the prepared $\mathrm{ZrO}_{2} / \mathrm{g}-\mathrm{C}_{3} \mathrm{~N}_{4}$ exhibited higher catalytic activity and degradation rate than $\mathrm{TiO}_{2}$ powder.

Figure 5 shows the photocatalytic activity of $30 \mathrm{wt} \%$ $\mathrm{ZrO}_{2} / \mathrm{g}-\mathrm{C}_{3} \mathrm{~N}_{4}$ with different scavengers (2-propanol (IPA), $\mathrm{KBrO}_{3}$, benzoquinone (BQ), $\mathrm{KI}$, and $\mathrm{NaF}$ ). From Fig. 5, it can be observed that IPA which is ' $\mathrm{OH}$ scavenger (He et al. 2013; Li et al. 2009) showed little impact on the reaction rate $(k)$ of 4-NP degradation. Although, the addition of $\mathrm{BQ}$, which is ${ }^{\cdot} \mathrm{O}^{-2}$ scavenger (Cui et al. 2013; Yang et al. 2013), decreased the $k$ from 0.0317 to $0.0063 \mathrm{~min}^{-1}$. The $k$ also had a clear drop to $0.0078 \mathrm{~min}^{-1}$ in the existence of $\mathrm{KI}\left(h^{+}\right.$and -OH scavenger) (He et al. 2013; Li et al. 2009). This result
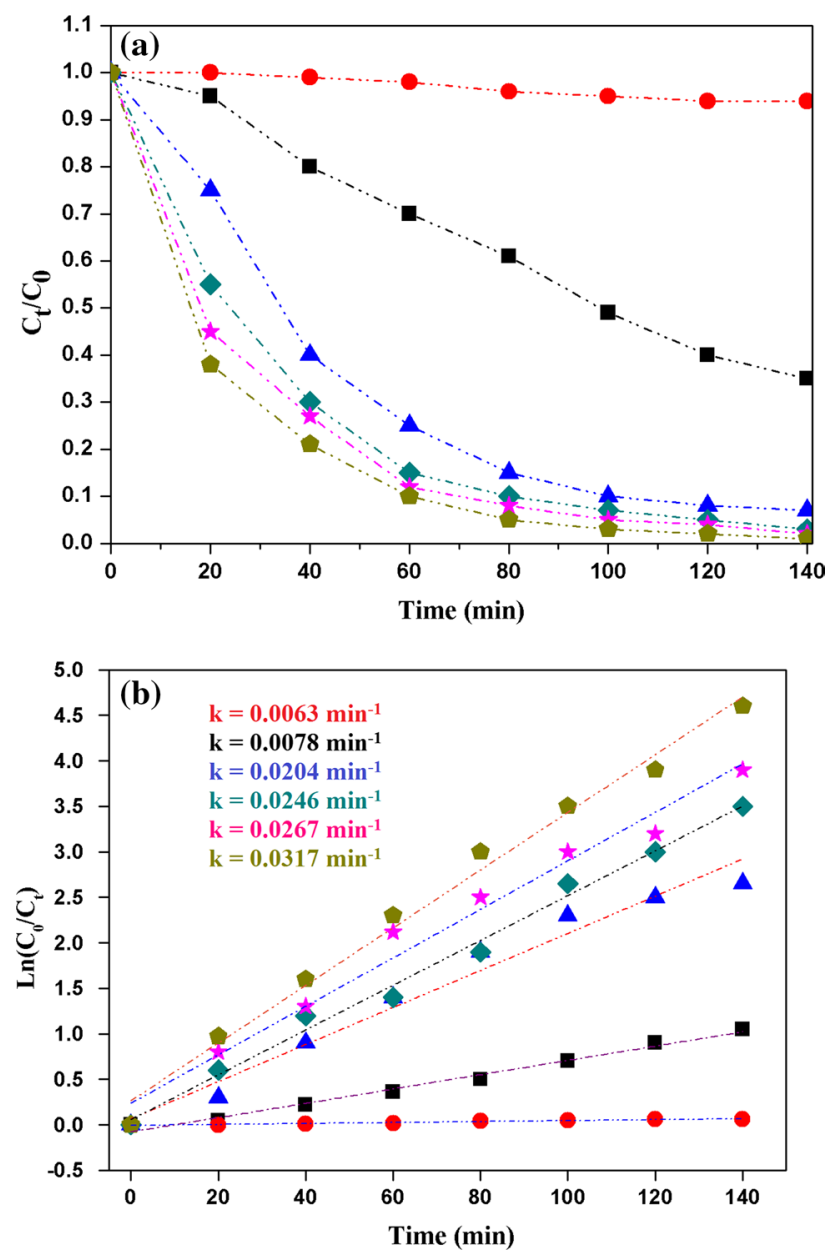

Fig. 5 Effects of scavengers on the photodegradation of 4-NP by $\mathrm{ZrO}_{2} / \mathrm{g}_{-} \mathrm{C}_{3} \mathrm{~N}_{4}$ (red color circle: $\mathrm{BQ}$, block color square: $\mathrm{KI}$, pink color star: IPA, light green color diamond: $\mathrm{NaF}$, blue color triangle: $\mathrm{KBrO}_{3}$, dark green color pentagon: no scavenger) demonstrates the role of $h^{+}$and $\cdot \mathrm{O}^{-2}$ in the photocatalytic degradation of 4-NP on $\mathrm{ZrO}_{2} / \mathrm{g}-\mathrm{C}_{3} \mathrm{~N}_{4}$ nanocomposites.

\section{Photoelectrochemical measurement}

Transient photocurrent response was measured to investigate the separation efficiency of photogenerated electrons and holes pairs of the $\mathrm{ZrO}_{2} \mathrm{NPs}, \mathrm{g}-\mathrm{C}_{3} \mathrm{~N}_{4}$ nanosheets, $\mathrm{ZrO}_{2} / \mathrm{g}-\mathrm{C}_{3} \mathrm{~N}_{4}$ nanocomposite. As shown in Fig. $6 \mathrm{a}, \mathrm{ZrO}_{2}$, g- $\mathrm{C}_{3} \mathrm{~N}_{4}$, and $\mathrm{ZrO}_{2} / \mathrm{g}-\mathrm{C}_{3} \mathrm{~N}_{4}$ samples demonstrated good reproducibility and stability under several on-off cycles of light illumination. However, the $\mathrm{ZrO}_{2} / \mathrm{g}-\mathrm{C}_{3} \mathrm{~N}_{4}$ exhibited stronger and higher photocurrent than $\mathrm{ZrO}_{2}$ and $\mathrm{g}-\mathrm{C}_{3} \mathrm{~N}_{4}$. The reason for this response in hybrid sample related to the existence of numerous charge carriers which enhances the photocatalytic
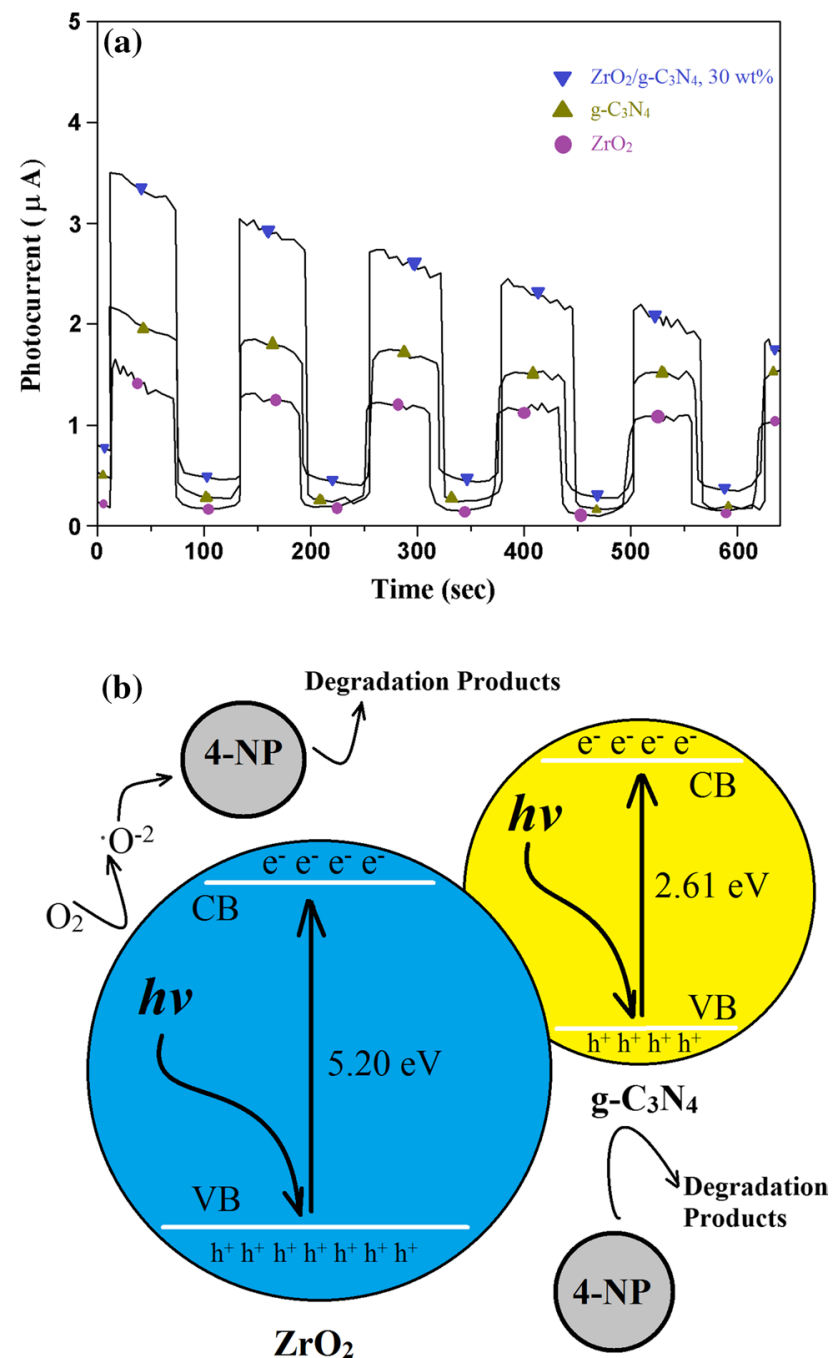

Fig. 6 a Transient photocurrent responses of pure $\mathrm{ZrO}_{2}, \mathrm{~g}-\mathrm{C}_{3} \mathrm{~N}_{4}$, and $\mathrm{ZrO}_{2} / \mathrm{g}-\mathrm{C}_{3} \mathrm{~N}_{4}$ nanocomposites under visible-light irradiation, b schematic of electron-hole pairs separation and the possible reaction mechanism on $\mathrm{ZrO}_{2} / \mathrm{g}-\mathrm{C}_{3} \mathrm{~N}_{4}$ nanocomposite under light irradiation 
activity. Furthermore, it confirms the strong interaction of $\mathrm{ZrO}_{2} \mathrm{NPs}$ and $\mathrm{g}-\mathrm{C}_{3} \mathrm{~N}_{4}$ nanosheets in hybrid sample.

\section{Photocatalytic mechanism}

Incorporation of $\mathrm{ZrO}_{2} \mathrm{NPs}$ on $\mathrm{g}_{-} \mathrm{C}_{3} \mathrm{~N}_{4}$ nanosheets generates an efficient photocatalyst for degradation of 4-NP under visible-light irradiation. The addition of $\mathrm{ZrO}_{2} \mathrm{NPs}$ can enhance the surface area and light absorption capacity of $\mathrm{g}_{-} \mathrm{C}_{3} \mathrm{~N}_{4}$ nanosheets. In general, two possible reaction mechanisms should be considered for the 4-NP degradation: (a) photolysis and (b) photocatalytic process. In photolysis, energy could be transferred from 4-NP to $\mathrm{O}_{2}$ to produce an oxygen atom $(\mathrm{O})$ which can oxidize 4-NP as follows:

$4-\mathrm{NP}+h v \rightarrow 4-\mathrm{NP}^{*}$

$4-\mathrm{NP}^{*}+\mathrm{O}_{2} \rightarrow 4-\mathrm{NP}+2 \mathrm{O}$

4-NP $+\mathrm{O} \rightarrow$ Degradation products.

Figure 4a shows no 4-NP degradation in the blank experiment under visible light, which confirms that the 4-NP is stable and the photolysis has a negligible contribution in the degradation of 4-NP. In the photocatalytic degradation by NPs, it can be described that the promotion of an electron from the valence band (VB) to the conduction band (CB) by light irradiation generates the active site (hole) for the oxidation of the 4-NP. According to the band gap structure of $\mathrm{ZrO}_{2} / \mathrm{g}-\mathrm{C}_{3} \mathrm{~N}_{4}$ and the influence and role of scavengers, possible pathway of the photocatalytic reaction with $\mathrm{ZrO}_{2} / \mathrm{g}-\mathrm{C}_{3} \mathrm{~N}_{4}$ was proposed (Eqs. 5-9). The schematic diagram of 4-NP degradation on $\mathrm{ZrO}_{2} / \mathrm{g}-\mathrm{C}_{3} \mathrm{~N}_{4}$ is illustrated in Fig. 6:

$\mathrm{ZrO}_{2} / \mathrm{g}-\mathrm{C}_{3} \mathrm{~N}_{4}+h v \rightarrow \mathrm{ZrO}_{2} / \mathrm{g}-\mathrm{C}_{3} \mathrm{~N}_{4}\left(e^{-}+h^{+}\right)$

$\mathrm{ZrO}_{2} / \mathrm{g}-\mathrm{C}_{3} \mathrm{~N}_{4}\left(e^{-}+h^{+}\right)+h v \rightarrow \mathrm{ZrO}_{2}\left(e^{-}\right) / \mathrm{g}-\mathrm{C}_{3} \mathrm{~N}_{4}\left(h^{+}\right)$

$\mathrm{ZrO}_{2}\left(e^{-}\right)+\mathrm{O}_{2} \rightarrow \cdot \mathrm{O}_{2}^{-}$

$\cdot \mathrm{O}_{2}^{-}+4-\mathrm{NP} \rightarrow$ Degradation products

g- $\mathrm{C}_{3} \mathrm{~N}_{4}\left(h^{+}\right)+4-\mathrm{NP} \rightarrow$ Degradation products.

Separation efficiency of electron-hole pairs plays an important role in photocatalytic degradation of 4-NP. Electrons of $\mathrm{ZrO}_{2} \mathrm{NPs}$ and $\mathrm{g}-\mathrm{C}_{3} \mathrm{~N}_{4}$ were excited from VB to $\mathrm{CB}$ which generated the holes in the VB for both semiconductors under the light irradiation. The $\mathrm{CB}$ of $\mathrm{g}-\mathrm{C}_{3} \mathrm{~N}_{4}$ nanosheet is more negative than that of $\mathrm{O}_{2}$ molecules (Song and Zhang 2008) which led to excitation of the electrons and diffusion to the $\mathrm{g}-\mathrm{C}_{3} \mathrm{~N}_{4}$ surface followed by reaction with oxygen molecules and generation of $\cdot \mathrm{O}^{-2}$ radicals. The highly reactive $\cdot \mathrm{O}^{-2}$ radicals have high oxidation capability and can degrade the 4-NP molecules on photocatalyst surface.
Further, the $\mathrm{CB}$ of $\mathrm{g}-\mathrm{C}_{3} \mathrm{~N}_{4}$ is more negative than that of $\mathrm{ZrO}_{2}$ and electrons on $\mathrm{g}_{-} \mathrm{C}_{3} \mathrm{~N}_{4}$ can directly move to the $\mathrm{CB}$ of $\mathrm{ZrO}_{2}$ NPs. Also, the VB of $\mathrm{ZrO}_{2}$ is more positive than the VB of g- $\mathrm{C}_{3} \mathrm{~N}_{4}$ and the holes on the $\mathrm{VB}$ of $\mathrm{ZrO}_{2}$ can directly move to the $\mathrm{VB}$ of $\mathrm{g}-\mathrm{C}_{3} \mathrm{~N}_{4}$. This process can effectively enhance the separation of electron-hole pairs and greatly decrease the charge recombination, resulting in the high photoactivity of $\mathrm{ZrO}_{2} / \mathrm{g}-\mathrm{C}_{3} \mathrm{~N}_{4}$ nanocomposites. The $\mathrm{VB}$ of $\mathrm{ZrO}_{2} / \mathrm{g}-\mathrm{C}_{3} \mathrm{~N}_{4}$ nanocomposites was evaluated according to the concepts of electronegativity. The VB of a semiconductor can be calculated by following equation (Zhang et al. 2009):

$E_{\mathrm{VB}}=X-E^{\mathrm{c}}+0.5 E_{\mathrm{g}}$

where $E_{\mathrm{VB}}$ is the VB potential, $E^{\mathrm{c}}$ is the energy of free electrons (about $4.5 \mathrm{eV}$ ), and $X$ is the electronegativity of the semiconductor. The value of $X$ for $\mathrm{ZrO}_{2}$ is $5.92 \mathrm{eV}$ (Jiang et al. 2010), and the $E_{\mathrm{VB}}$ for $\mathrm{ZrO}_{2}$ was calculated to be $4.11 \mathrm{eV}$. The conduction band edge potential, $E_{\mathrm{CB}}$, is calculated by:

$E_{\mathrm{CB}}=E_{\mathrm{VB}}-E_{\mathrm{g}}$.

The band gap of the $\mathrm{ZrO}_{2} \mathrm{NPs}$ is about $5.20 \mathrm{eV}$. The values of $E_{\mathrm{VB}}$ and $E_{\mathrm{CB}}$ for $\mathrm{g}-\mathrm{C}_{3} \mathrm{~N}_{4}$ were reported as 1.53 and $-1.01 \mathrm{eV}$, respectively (Yan et al. 2010).

\section{Efficiency of the catalyst}

To study the efficiency and stability of $\mathrm{ZrO}_{2} / \mathrm{g}-\mathrm{C}_{3} \mathrm{~N}_{4}$ nanocomposite, the photocatalytic degradation was repeated by a five-run cycling test under the same condition (Fig. 7). For each run, the photocatalyst was recycled, cleaned, and dried. In each cycle, the suspension was magnetically stirred for $2 \mathrm{~h}$ in the presence of light irradiation. The photodegradation of 4-NP was completed in each cycle. Hence, it is plausible

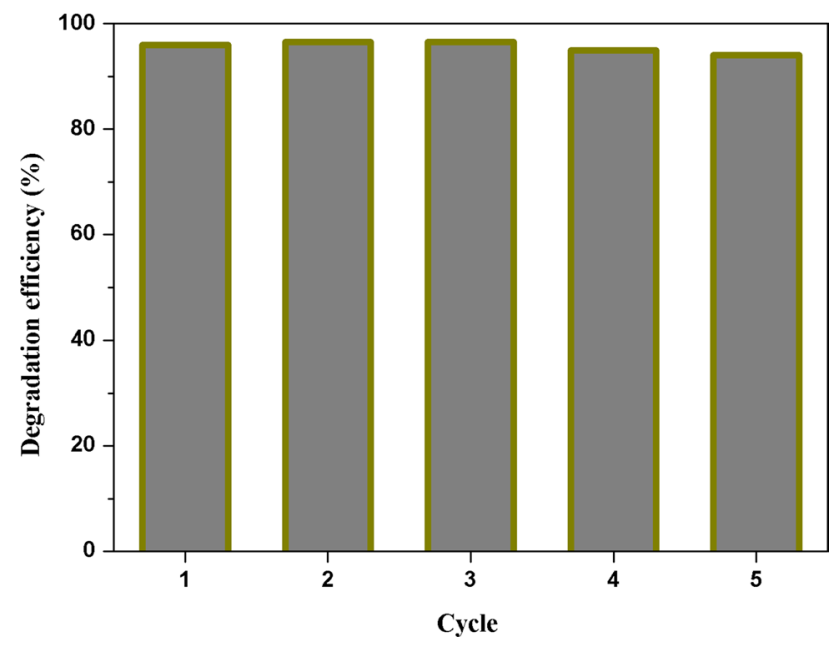

Fig. 7 Reusability of the $30 \mathrm{wt} \% \mathrm{ZrO}_{2} / g-\mathrm{C}_{3} \mathrm{~N}_{4}$ photocatalyst in successive cycles 
to say that there is no significant loss of catalytic activity even after five cycles.

\section{Conclusions}

Nanotechnology-based photocatalysis plays an important role in the future of environmental decontamination, water remediation, and renewable energy generation from water splitting. In this work, $\mathrm{ZrO}_{2} / \mathrm{g}-\mathrm{C}_{3} \mathrm{~N}_{4}$ composites were successfully synthesized via simple ultrasound method. The prepared $\mathrm{ZrO}_{2} / \mathrm{g}-\mathrm{C}_{3} \mathrm{~N}_{4}$ catalysts were used for photocatalytic degradation of 4-NP. $\mathrm{ZrO}_{2} / \mathrm{g}-\mathrm{C}_{3} \mathrm{~N}_{4}$ exhibited higher photocatalytic activity than pure $\mathrm{g}-\mathrm{C}_{3} \mathrm{~N}_{4}$ for the degradation of 4-NP under light irradiation, and the $30 \mathrm{wt} \% \mathrm{ZrO}_{2} / \mathrm{g}-\mathrm{C}_{3} \mathrm{~N}_{4}$ sample showed the highest activity. The $\mathrm{XRD}$, nitrogen sorption, and FESEM results revealed that the $\mathrm{ZrO}_{2} / \mathrm{g}-\mathrm{C}_{3} \mathrm{~N}_{4}$ catalysts have high specific surface area. The $\mathrm{ZrO}_{2} / \mathrm{g}-\mathrm{C}_{3} \mathrm{~N}_{4}$ nanocomposite is not only a good adsorbent but also a very efficient heterogeneous photocatalyst for the degradation of 4-NP. Moreover, this $\mathrm{ZrO}_{2} / g-\mathrm{C}_{3} \mathrm{~N}_{4}$ nanocomposite can be reused several times for photocatalytic degradation as well as for 4-NP adsorption. Thus, this $\mathrm{ZrO}_{2} / \mathrm{g}-\mathrm{C}_{3} \mathrm{~N}_{4}$ composite is a suitable catalyst for water cleaning. It has been shown the $\mathrm{ZrO}_{2} \mathrm{NPs}$ and $\mathrm{g}_{-} \mathrm{C}_{3} \mathrm{~N}_{4}$ nanosheets have unique properties such as antibacterial and antimicrobial behavior, environmental friendliness, and non-toxicity (Bing et al. 2015; Gowri et al. 2014). In fact, these characteristics besides the photocatalytic behaviors of $\mathrm{g}-\mathrm{C}_{3} \mathrm{~N}_{4}$ and $\mathrm{ZrO}_{2} \mathrm{NPs}$ present a great potential for application of $\mathrm{ZrO}_{2} / \mathrm{g}-\mathrm{C}_{3} \mathrm{~N}_{4}$ composite for water remediation purposes.

Acknowledgements The authors acknowledge University of Kurdistan for supporting this project.

Open Access This article is distributed under the terms of the Creative Commons Attribution 4.0 International License (http://creativeco mmons.org/licenses/by/4.0/), which permits unrestricted use, distribution, and reproduction in any medium, provided you give appropriate credit to the original author(s) and the source, provide a link to the Creative Commons license, and indicate if changes were made.

\section{References}

Anbia M, Haqshenas M (2015) Adsorption studies of $\mathrm{Pb}(\mathrm{II})$ and $\mathrm{Cu}(\mathrm{II})$ ions on mesoporous carbon nitride functionalized with melaminebased dendrimer amine. Int J Environ Sci Technol 12:2649-2664

Atlow SC, Bonadonna-Aparo L, Klibanov AM (1984) Dephenolization of industrial wastewaters catalyzed by polyphenol oxidase. Biotechnol Bioeng 26:599-603

Bing W, Chen Z, Sun H, Shi P, Gao N, Ren J, Qu X (2015) Visiblelight-driven enhanced antibacterial and biofilm elimination activity of graphitic carbon nitride by embedded Ag nanoparticles. Nano Res 8:1648-1658
Campelo JM, Luna D, Luque R, Marinas JM, Romero AA (2009) Sustainable preparation of supported metal nanoparticles and their applications in catalysis. Chemsuschem 2:18-45

Chang G, Luo Y, Lu W, Qin X, Asiri AM, Al-Youbi AO, Sun X (2012) Ag nanoparticles decorated polyaniline nanofibers: synthesis, characterization, and applications toward catalytic reduction of 4-nitrophenol and electrochemical detection of $\mathrm{H}_{2} \mathrm{O}_{2}$ and glucose. Catal Sci Technol 2:800-806

Chen Q, Zhao Y, Huang X, Chen N, Qu L (2015) Three-dimensional graphitic carbon nitride functionalized graphene-based high-performance supercapacitors. J Mater Chem A 3:6761-6766

Cui $\mathrm{H}$ et al (2013) Facile synthesis of graphene oxide-enwrapped $\mathrm{Ag}_{3} \mathrm{PO}_{4}$ composites with highly efficient visible light photocatalytic performance. Mater Lett 93:28-31

Fidelus JD, Karbowski A, Mariazzi S, Werner-Malento E, Brusa RS, Zhou W, Karwasz GP (2012) Combined positron-annihilation and structural studies of hydrothermally grown zirconia. Nanomater Energy 1:97-105

Gao H, Yan S, Wang J, Zou Z (2014) Ion coordination significantly enhances the photocatalytic activity of graphitic-phase carbon nitride. Dalton Trans 43:8178-8183

Ge L, Han C, Xiao X, Guo L (2013) Synthesis and characterization of composite visible light active photocatalysts $\mathrm{MoS}_{2}-\mathrm{gC}_{3} \mathrm{~N}_{4}$ with enhanced hydrogen evolution activity. Int J Hydrog Energy 38:6960-6969

Geim AK (2009) Graphene: status and prospects. Science 324:1530-1534

Gowri S, Gandhi RR, Sundrarajan M (2014) Structural, optical, antibacterial and antifungal properties of zirconia nanoparticles by biobased protocol. J Mater Sci Technol 30:782-790

Guo S, Dong S (2011) Graphene nanosheet: synthesis, molecular engineering, thin film, hybrids, and energy and analytical applications. Chem Soc Rev 40:2644-2672

He Y, Cai J, Li T, Wu Y, Lin H, Zhao L, Luo M (2013) Efficient degradation of $\mathrm{RhB}$ over $\mathrm{GdVO}_{4} / \mathrm{g}-\mathrm{C}_{3} \mathrm{~N}_{4}$ composites under visible-light irradiation. Chem Eng J 215:721-730

Hu R, Wang X, Dai S, Shao D, Hayat T, Alsaedi A (2015) Application of graphitic carbon nitride for the removal of $\mathrm{Pb}$ (II) and aniline from aqueous solutions. Chem Eng J 260:469-477

Huang Z-F et al (2015) Carbon nitride with simultaneous porous network and O-doping for efficient solar-energy-driven hydrogen evolution. Nano Energy 12:646-656

Jiang H, Gomez-Abal RI, Rinke P, Scheffler M (2010) Electronic band structure of zirconia and hafnia polymorphs from the $\mathrm{G} W$ perspective. Phys Rev B 81:085119

Jiang F, Yan T, Chen H, Sun A, Xu C, Wang X (2014) A g- $\mathrm{C}_{3} \mathrm{~N}_{4}-\mathrm{CdS}$ composite catalyst with high visible-light-driven catalytic activity and photostability for methylene blue degradation. Appl Surf Sci 295:164-172

Klibanov AM, Tu T-M, Scott KP (1983) Peroxidase-catalyzed removal of phenols from coal-conversion waste waters. Science 221:259-261

Lan M, Fan G, Yang L, Li F (2015) Enhanced visible-light-induced photocatalytic performance of a novel ternary semiconductor coupling system based on hybrid $\mathrm{Zn}$-In mixed metal oxide/g- $\mathrm{C}_{3} \mathrm{~N}_{4}$ composites. RSC Adv 5:5725-5734

Leary R, Westwood A (2011) Carbonaceous nanomaterials for the enhancement of $\mathrm{TiO}_{2}$ photocatalysis. Carbon 49:741-772

Li G, Wong K, Zhang X, Hu C, Jimmy CY, Chan R, Wong P (2009) Degradation of acid orange 7 using magnetic $\mathrm{AgBr}$ under visible light: the roles of oxidizing species. Chemosphere 76:1185-1191

$\mathrm{Li} \mathrm{G}$ et al (2015) Enhanced visible-light-driven photocatalytic inactivation of Escherichia coli using $\mathrm{g}-\mathrm{C}_{3} \mathrm{~N}_{4} / \mathrm{TiO}_{2}$ hybrid photocatalyst synthesized using a hydrothermal-calcination approach. Water Res 86:17-24 
Liang Q, Li Z, Yu X, Huang ZH, Kang F, Yang QH (2015) Macroscopic 3D porous graphitic carbon nitride monolith for enhanced photocatalytic hydrogen evolution. Adv Mater 27:4634-4639

Liu G, Wang Y, Shen C, Ju Z, Yuan D (2015a) A facile synthesis of microporous organic polymers for efficient gas storage and separation. J Mater Chem A 3(6):3051-3058

Liu J et al (2015b) Metal-free efficient photocatalyst for stable visible water splitting via a two-electron pathway. Science 347:970-974

Lu Y-C, Chen J, Wang A-J, Bao N, Feng J-J, Wang W, Shao L (2015) Facile synthesis of oxygen and sulfur co-doped graphitic carbon nitride fluorescent quantum dots and their application for mercury (II) detection and bioimaging. J Mater Chem C 3:73-78

Luo WB, Chou SL, Wang JZ, Zhai YC, Liu HK (2015) A metalfree, free-standing, macroporous graphene@ $\mathrm{g}-\mathrm{C}_{3} \mathrm{~N}_{4}$ composite air electrode for high-energy lithium oxygen batteries. Small 11:2817-2824

Maeda K, Kuriki R, Zhang M, Wang X, Ishitani O (2014) The effect of the pore-wall structure of carbon nitride on photocatalytic $\mathrm{CO}_{2}$ reduction under visible light. J Mater Chem A 2:15146-15151

Mao J, Peng T, Zhang X, Li K, Ye L, Zan L (2013) Effect of graphitic carbon nitride microstructures on the activity and selectivity of photocatalytic $\mathrm{CO}_{2}$ reduction under visible light. Catal Sci Technol 3:1253-1260

Ong W-J, Tan L-L, Chai S-P, Yong S-T (2015a) Graphene oxide as a structure-directing agent for the two-dimensional interface engineering of sandwich-like graphene- $\mathrm{gC}_{3} \mathrm{~N}_{4}$ hybrid nanostructures with enhanced visible-light photoreduction of $\mathrm{CO}_{2}$ to methane. Chem Commun 51:858-861

Ong W-J, Tan L-L, Chai S-P, Yong S-T (2015b) Heterojunction engineering of graphitic carbon nitride $\left(\mathrm{gC}_{3} \mathrm{~N}_{4}\right)$ via Pt loading with improved daylight-induced photocatalytic reduction of carbon dioxide to methane. Dalton Trans 44:1249-1257

Pany S, Parida K (2015) A facile in situ approach to fabricate N, $\mathrm{S}-\mathrm{TiO}_{2} / \mathrm{g}_{-} \mathrm{C}_{3} \mathrm{~N}_{4}$ nanocomposite with excellent activity for visible light induced water splitting for hydrogen evolution. Phys Chem Chem Phys 17:8070-8077

Papailias I, Giannakopoulou T, Todorova N, Demotikali D, Vaimakis T, Trapalis C (2015) Effect of processing temperature on structure and photocatalytic properties of $\mathrm{g}-\mathrm{C}_{3} \mathrm{~N}_{4}$. Appl Surf Sci 358:278-286

Pawar RC, Kang S, Ahn SH, Lee CS (2015) Gold nanoparticle modified graphitic carbon nitride/multi-walled carbon nanotube $\left(\mathrm{g}-\mathrm{C}_{3} \mathrm{~N}_{4} /\right.$ $\mathrm{CNTs} / \mathrm{Au}$ ) hybrid photocatalysts for effective water splitting and degradation. RSC Adv 5:24281-24292

Pawar RC, Kang S, Park JH, Kim J-H, Ahn S, Lee CS (2016a) Roomtemperature synthesis of nanoporous $1 \mathrm{D}$ microrods of graphitic carbon nitride $\left(\mathrm{g}-\mathrm{C}_{3} \mathrm{~N}_{4}\right)$ with highly enhanced photocatalytic activity and stability. Sci Rep 6:31147

Pawar RC, Son Y, Kim J, Ahn SH, Lee CS (2016b) Integration of $\mathrm{ZnO}$ with $\mathrm{g}-\mathrm{C}_{3} \mathrm{~N}_{4}$ structures in core-shell approach via sintering process for rapid detoxification of water under visible irradiation. Curr Appl Phys 16:101-108

Pawar RC, Kang S, Park JH, Kim J-H, Ahn S, Lee CS (2017) Evaluation of a multi-dimensional hybrid photocatalyst for enrichment of $\mathrm{H} 2$ evolution and elimination of dye/non-dye pollutants. Catal Sci Technol 7:2579-2590

Pohanish RP (2008) Sittig's handbook of toxic and hazardous chemicals and carcinogens. William Andrew, Norwich

Polisetti S, Deshpande PA, Madras G (2011) Photocatalytic activity of combustion synthesized $\mathrm{ZrO} 2$ and $\mathrm{ZrO} 2-\mathrm{TiO} 2$ mixed oxides. Ind Eng Chem Res 50:12915-12924

Pradhan N, Pal A, Pal T (2002) Silver nanoparticle catalyzed reduction of aromatic nitro compounds. Colloids Surf A 196:247-257

Reimer T et al (2014) Single step integration of $\mathrm{ZnO}$ nano-and microneedles in Si trenches by novel flame transport approach: whispering gallery modes and photocatalytic properties. ACS Appl Mater Interfaces 6:7806-7815

Sayama K, Arakawa H (1993) Photocatalytic decomposition of water and photocatalytic reduction of carbon dioxide over zirconia catalyst. J Phys Chem 97:531-533

Singh A, Nakate UT (2014) Microwave synthesis, characterization, and photoluminescence properties of nanocrystalline zirconia. Sci World J Article ID 349457:1-7

Song C, Zhang J (2008) Electrocatalytic oxygen reduction reaction. In: PEM fuel cell electrocatalysts and catalyst layers. Springer, pp 89-134

Sridharan K, Kuriakose T, Philip R, Park TJ (2014) Transition metal $(\mathrm{Fe}, \mathrm{Co}$ and $\mathrm{Ni}$ ) oxide nanoparticles grafted graphitic carbon nitrides as efficient optical limiters and recyclable photocatalysts. Appl Surf Sci 308:139-147

Tan L-L, Ong W-J, Chai S-P, Goh BT, Mohamed AR (2015) Visiblelight-active oxygen-rich $\mathrm{TiO}_{2}$ decorated $2 \mathrm{D}$ graphene oxide with enhanced photocatalytic activity toward carbon dioxide reduction. Appl Catal B Environ 179:160-170

Tian J, Liu Q, Asiri AM, Al-Youbi AO, Sun X (2013) Ultrathin graphitic carbon nitride nanosheet: a highly efficient fluorosensor for rapid, ultrasensitive detection of $\mathrm{Cu}^{2+}$. Anal Chem 85:5595-5599

Tian J, Ning R, Liu Q, Asiri AM, Al-Youbi AO, Sun X (2014) Threedimensional porous supramolecular architecture from ultrathin g- $\mathrm{C}_{3} \mathrm{~N}_{4}$ nanosheets and reduced graphene oxide: solution selfassembly construction and application as a highly efficient metalfree electrocatalyst for oxygen reduction reaction. ACS Appl Mater Interfaces 6:1011-1017

Wang D, Astruc D (2014) Fast-growing field of magnetically recyclable nanocatalysts. Chem Rev 114:6949-6985

Wang X et al (2009) A metal-free polymeric photocatalyst for hydrogen production from water under visible light. Nat Mater 8:76-80

Wang Y, Wang X, Antonietti M (2012) Polymeric graphitic carbon nitride as a heterogeneous organocatalyst: from photochemistry to multipurpose catalysis to sustainable chemistry. Angew Chem Int Ed 51:68-89

Wang H, Lu J, Wang F, Wei W, Chang Y, Dong S (2014) Preparation, characterization and photocatalytic performance of g- $\mathrm{C}_{3} \mathrm{~N}_{4} /$ $\mathrm{Bi}_{2} \mathrm{WO}_{6}$ composites for methyl orange degradation. Ceram Int 40:9077-9086

Wang L, Zhao F, Han Q, Hu C, Lv L, Chen N, Qu L (2015) Spontaneous formation of $\mathrm{Cu}_{2} \mathrm{O}-\mathrm{g}-\mathrm{C}_{3} \mathrm{~N}_{4}$ core-shell nanowires for photocurrent and humidity responses. Nanoscale 7:9694-9702

Woan K, Pyrgiotakis G, Sigmund W (2009) Photocatalytic carbonnanotube- $\mathrm{TiO}_{2}$ composites. Adv Mater 21:2233-2239

Wu Z, Gao H, Yan S, Zou Z (2014) Synthesis of carbon black/carbon nitride intercalation compound composite for efficient hydrogen production. Dalton Trans 43:12013-12017

Xu H, Ouyang S, Liu L, Reunchan P, Umezawa N, Ye J (2014) Recent advances in $\mathrm{TiO}_{2}$-based photocatalysis. J Mater Chem A 2:12642-12661

$\mathrm{Xu} \mathrm{L}$ et al (2015) Insights into enhanced visible-light photocatalytic hydrogen evolution of g-C3N4 and highly reduced graphene oxide composite: the role of oxygen. Chem Mater 27:1612-1621

Yan S, Li Z, Zou Z (2009) Photodegradation performance of g- $\mathrm{C}_{3} \mathrm{~N}_{4}$ fabricated by directly heating melamine. Langmuir 25:10397-10401

Yan S, Lv S, Li Z, Zou Z (2010) Organic-inorganic composite photocatalyst of $\mathrm{g}_{-} \mathrm{C}_{3} \mathrm{~N}_{4}$ and $\mathrm{TaON}$ with improved visible light photocatalytic activities. Dalton Trans 39:1488-1491

Yang X, Cui H, Li Y, Qin J, Zhang R, Tang H (2013) Fabrication of $\mathrm{Ag}_{3} \mathrm{PO}_{4}$-graphene composites with highly efficient and stable visible light photocatalytic performance. ACS Catal 3:363-369

Yang J, Zhang H, Chen B, Tang H, Li C, Zhang Z (2015a) Fabrication of the $\mathrm{gC}_{3} \mathrm{~N}_{4} / \mathrm{Cu}$ nanocomposite and its potential for lubrication applications. RSC Adv 5:64254-64260 
Yang Q, Wang W, Zhao Y, Zhu J, Zhu Y, Wang L (2015b) Metal-free mesoporous carbon nitride catalyze the Friedel-Crafts reaction by activation of benzene. RSC Adv 5:54978-54984

Yeh T-F, Chen S-J, Teng H (2015) Synergistic effect of oxygen and nitrogen functionalities for graphene-based quantum dots used in photocatalytic $\mathrm{H}_{2}$ production from water decomposition. Nano Energy 12:476-485

Yi J, Liao K, Zhang C, Zhang T, Li F, Zhou H (2015) Facile in situ preparation of graphitic- $\mathrm{C}_{3} \mathrm{~N}_{4}$ @ carbon paper as an efficient metal-free cathode for nonaqueous $\mathrm{Li}-\mathrm{O}_{2}$ battery. ACS Appl Mater Interfaces 7:10823-10827

Zarei M, Seif A, Azizi K, Zarei M, Bahrami J (2016) Effect of phenolic radicals on the geometry and electronic structure of DNA base pairs: computational study. Int J Mod Phys C 27:1650119

Zhang X, Zhang L, Xie T, Wang D (2009) Low-temperature synthesis and high visible-light-induced photocatalytic activity of BiOI/ $\mathrm{TiO}_{2}$ heterostructures. J Phys Chem C 113:7371-7378

Zhang Q, Zhang Y, Li H, Gao C, Zhao Y (2013) Heterogeneous CaO$\mathrm{ZrO}_{2}$ acid-base bifunctional catalysts for vapor-phase selective dehydration of 1, 4-butanediol to 3-buten-1-ol. Appl Catal A Gen 466:233-239

Zhang H et al (2015a) Self-assembly of graphitic carbon nitride nanosheets-carbon nanotube composite for electrochemical simultaneous determination of catechol and hydroquinone. Electrochim Acta 176:28-35

Zhang P, Wang T, Gong J (2015b) Mechanistic understanding of the plasmonic enhancement for solar water splitting. Adv Mater 27:5328-5342

Zhao Y, Zhang Y, Li J, Du X (2014) Solvothermal synthesis of visible-light-active $\mathrm{N}$-modified $\mathrm{ZrO}_{2}$ nanoparticles. Mater Lett 130:139-142

Zhao L et al (2015) A chromium nitride/carbon nitride containing graphitic carbon nanocapsule hybrid as a Pt-free electrocatalyst for oxygen reduction. Chem Commun 51:12399-12402

Zheng Y, Liu J, Liang J, Jaroniec M, Qiao SZ (2012) Graphitic carbon nitride materials: controllable synthesis and applications in fuel cells and photocatalysis. Energy and Environ Sci 5:6717-6731

Publisher's Note Springer Nature remains neutral with regard to jurisdictional claims in published maps and institutional affiliations. 